\title{
Computerized cognitive stimulation for people with dementia or with mild cognitive impairment: a bibliometric review
}

\begin{abstract}
Sónia Rolland Sobral ${ }^{\oplus}$, Margarida Sobral2,3 $\odot$
ABSTRACT. Many studies have found that non-pharmacological interventions, such as cognitive stimulation (CS), can benefit people with dementia (PWD) or with mild cognitive impairment (MCI). The use of the computerized cognitive stimulation (CCS) had proven to be an ally to those who want to detect and mitigate this disease. Objective: The purpose of this paper was to analyze the scientific production in CCS in PWD or with MCl in journals indexed in Clarivate Analytics' Web of Science and Elsevier's Scopus since 2000. Methods: Data collected from Web of Science and Scopus during 2000-2019. Results: The data show that dementia research is exponentially developing following the evolution of widespread use of computer science. As such, this article was of enormous importance doing a bibliometric analysis of what has been done in the area since the beginning of this century. The search terms identified 61 papers related to the use of computers applied to CS in PWD or MCl, and the International Journal of Geriatric Psychiatry and Journal of Alzheimer's Disease had the largest number of publications. The most cited article was the Faucounau et colleagues. Major research' countries are United Kingdom, Spain and United States. Conclusions: The findings in these papers were analysed to find recommendations for future work in this area. The CCS has been increasingly used as an intervention tool for PWD or MCl, and there still seems to be a possibility for evolution in good quality publications.
\end{abstract}

Keywords: bibliometrics, cognition, computers, data analysis, dementia.

\section{ESTIMULAÇ̃̃O COGNITIVA COMPUTADORIZADA PARA PESSOAS COM DEMÊNCIA OU DECLÍNIO COGNITIVO LIGEIRO: UMA REVISÃO BIBLIOMÉTRICA}

RESUMO. Muitos estudos têm demonstrado que as intervenções não farmacológicas, como a estimulação cognitiva (EC), podem beneficiar pessoas com demência (PCD) ou com declínio cognitivo ligeiro (DCL). 0 uso da estimulação cognitiva computadorizada (ECC) tem mostrado ser um meio para detetar e mitigar essa doença. Objetivo: 0 objetivo do presente artigo foi analisar a produção científica em ECC em PCD ou com DCL publicada em revistas indexadas na Web of Science da Clarivate Analytics e na Scopus da Elsevier desde 2000. Métodos: Os dados foram coletados na Web of Science e Scopus relativamente aos anos 2000-2019. Resultados: 0s dados mostram que a pesquisa em demência está se desenvolvendo exponencialmente, acompanhando a evolução do uso generalizado da ciência da computação. Dessa forma, o estudo foi de enorme importância para uma análise bibliométrica do que tem sido feito na área desde o início deste século. Os termos de pesquisa identificaram 61 artigos relacionados ao uso de computadores aplicados à EC em PCD ou DCL, e ambos os periódicos International Journal of Geriatric Psychiatry e Journal of Alzheimer's Disease tiveram o maior número de publicações. 0 artigo mais citado foi o de Faucounau et al. Os principais países de pesquisa foram Reino Unido, Espanha e Estados Unidos. Conclusões: Os resultados desses artigos foram analisados de forma a possibilitar encontrar recomendações para trabalhos futuros nessa área. A ECC tem sido cada vez mais utilizada como ferramenta nas intervenções para PCD e DCL, e ainda parece haver possibilidade de evolução em publicações de boa qualidade.

Palavras-chave: bibliometria, estimulação cognitiva, computadores, análise de dados, demência.

\footnotetext{
This study was conducted at the Universidade Portucalense Infante D. Henrique, Porto, Portugal, and Hospital Magahães Lemos, Porto, Portugal.

'Universidade Portucalense - Porto, Portugal.

2Psychogeriatrics Service, Hospital Magalhães Lemos - Porto, Portugal.

${ }^{3}$ Center for Health Technology and Services Research - Porto, Portugal.

Margarida Sobral. Hospital de Magalhães Lemos. Rua do Professor Álvaro Rodrigues - 4149-003 Porto - Portugal. E-mail: margaridasobra@@hmlemos.min-saude.pt

Disclosure: The authors report no conflicts of interest.

Funding: none.

Received on June 30, 2020. Accepted in final form on October 02, 2020.
}

\section{(c) BY}




\section{INTRODUCTION}

Dementia is a disorder characterized by deterioration of cognitive and functional abilities and several neuropsychiatry and behavioral symptoms. ${ }^{1,2}$ The most common dementia is Alzheimer's disease (AD), which is a degenerative disease, what means that it becomes worse with time. ${ }^{1}$ The risk of dementia rises with increasing age, and this disease has a huge economic impact. Mild cognitive impairment (MCI) is characterized by an objective cognitive decline in one or more cognitive domains without any significant impairment in daily life activities. ${ }^{3}$ In fact, the $\mathrm{MCI}$ is the expected stage between the cognitive decline result of the normal aging and the more serious decline of dementia, and may increase the risk of dementia later developing caused by AD or other neurological conditions. Given the unprecedented personal, societal, and healthcare costs, it is not surprising that global efforts to develop and implement dementia risk reduction strategies are occurring. ${ }^{4,5}$

People with dementia (PWD) experience multiple symptoms that change over a period of years, and these symptoms reflect the degree of damage to nerve cells, wherein the pace at which symptoms of dementia advance from mild to moderate to severe differs from person to person. ${ }^{1}$ Though there is no cure for $\mathrm{AD}$, there are some treatments available to ease symptoms and slow the disease progression.

Non-pharmacological interventions in combination with pharmacotherapies have been considered the best approach in the management of $\mathrm{PWD}^{6-8}$ and many studies have found that non-pharmacological interventions, such as cognitive stimulation (CS), can benefit PWD. ${ }^{7,9-11}$ There has been an interest in a variety of technological interventions that can treat symptoms of cognitive, behavioral and psychological impairment. CS is a non-pharmacological intervention to treat people with mild to moderate dementia. ${ }^{12}$ According to Piasek et al., ${ }^{13}$ in the absence of a cure for dementia, there is a real need to develop user-centered technologies to enhance the well-being and quality of life of PWD.

The use of the computer, in its different types, has proven to be an ally to those who want to detect and mitigate this disease. Computerized cognitive training programs may be used as a practical and valuable tool in clinic to improve cognitive status. ${ }^{14,15}$ García-Casal et al. ${ }^{16}$ found that the computer-based cognitive interventions had moderate effects in cognition. However, they led to superior results compared to non-computer-based interventions in cognition.

Dementia and non-pharmacological interventions research, such as computerized cognitive stimulation (CCS), is exponentially developing following the evolution of widespread use of computer. As such, this article intended to be of enormous importance doing a bibliometric analysis about what has been done in the area since the beginning of this century. The motivation for this research was based on our desire to know and clarify the impact of non-pharmacological interventions using a computer and its advantages over the use of traditional methods of CS and to know what has been published in this area. This review is different from all other existing reviews, as it managed to cover a wide range of articles, with key information to understand the impact of the use of technologies in the areas of non-pharmacological interventions. The purpose of this paper was to analyze the scientific production in CCS and PWD or people with MCI in journals indexed in Clarivate Analytics' Web of Science and Elsevier's Scopus.

This document is divided into several sections. First, the research questions are described, followed by the methodology and the results. Then, a summary of the most cited articles is made, as well as an analysis of all documents in the database, ending with a discussion of the results obtained and the conclusions, including a suggested future work.

\section{THE RESEARCH QUESTIONS}

The question, along with the purpose of the review, the intended deliverables and the intended audience, determines how the data are identified, collected and presented. ${ }^{17}$ There are several questions that we want to answer in this paper:

- Q1: When were the articles published?

- Q2: Where were the articles published?

- Q3: What is the focus of the articles? Has it evolved over the years?

- Q4: Who publishes on the subject? Where do researchers who are interested in PWD work? What country do they live in?

- Q5: What are the most cited articles?

\section{METHODS}

The term "bibliometrics" was first used in 1969 by Alan Pritchard, hoping that it would be used explicitly in all studies which seek to quantify the processes of written communication and would quickly gain acceptance in the field of information science. ${ }^{18}$ Moed mentioned the potential of this type of study that reveals the enormous potential of quantitative, bibliometric analyses of the scholarly literature for a deeper understanding of scholarly activity and performance, and highlights their policy relevance. ${ }^{19}$ In scientific research, it is important to get a comprehensive perspective of research already 
being conducted concerning a relevant subject matter ${ }^{20}$ and a bibliometric analysis profile on the research trajectory and dynamics of the research activities across the globe. ${ }^{21}$ This is a bibliometric study that systematically analyses the literature using two at Elsevier's Scopus (Scopus) and Clarivate Analytics' Web of Science (WoS) databases. This paper conducts a bibliometric analysis of international papers that we expect to provide a useful reference for future research.

The research strategy was designed by the authors according to the literature review previously prepared. In this case, the terms that are identified as relevant to the present study were defined, the time frame (from 2000 to 2019), and the type of publication identified as relevant to the research.

The Scopus search strategy was:

- TITLE-ABS-KEY ("cognitive stimulation" AND comput* AND "dementia”).

- DocType: Article OR Review OR Conference Paper.

- PUBYEAR: >1999 AND <2020.

The WoS search strategy was:

- TS=("cognitive stimulation" AND comput* AND "dementia").

- Document Type $=($ ARTICLE OR MEETING OR REVIEW).

- $\mathrm{PY}=(2000-2019)$.

The eligible papers were required to: (a) include participants with a diagnosis of dementia or MCI using a validated cognitive screening measure; (b) examine the effects of CCS; (c) include case series, control group, randomized or non randomized design.

\section{RESULTS}

A set of 48 published papers were collected from WoS and 35 from Scopus. The search returned a total of 61 articles and reviews after discounting the duplicate results. Thus, this bibliometric study analyzed the literature using 17 articles from Scopus, ${ }^{13,22-27} 27$ from WoS, ${ }^{12,16,28-34}$ and 17 articles indexed in both databases. ${ }^{35-44}$ In the articles studied, the trials included most were unregistered, parallel-group or single-site randomised controlled trials. The first article was published in 2005 (Figure 1). The average number of articles is 4 per year. The year with the greatest number of articles is $2018 .^{10}$ We can observe in Figure 1 that both curves of publications have an increasing trend until 2018 in both datasets, due to the progress of scientific literature in this field of research. We noted that in the last year there has been a decrease in published papers.

There are 50 sources of publications: only two journals have three publications (International Journal of Geriatric Psychiatry and Journal of Alzheimer's Disease) and seven others have two publications (one of these is ACM International Conference Proceeding Series) (Table 1). Most of these journals are from the first quartile, three are from United Kingdom and three from United States.

Most articles are written by three authors (21\%), $15 \%$ are written by five authors and $10 \%$ by two authors.

There are 320 authors. Only three of these 320 wrote three articles. The authors with three articles were Hiroko Hayama Dodge from the University of Michigan, (Ann Arbor, United States), Hermine Lenoir from the Université Paris Descartes (Paris, France) and Victoria Meza-Kubo from the Universidad Autónoma de Baja California (Ensenada, Mexico).

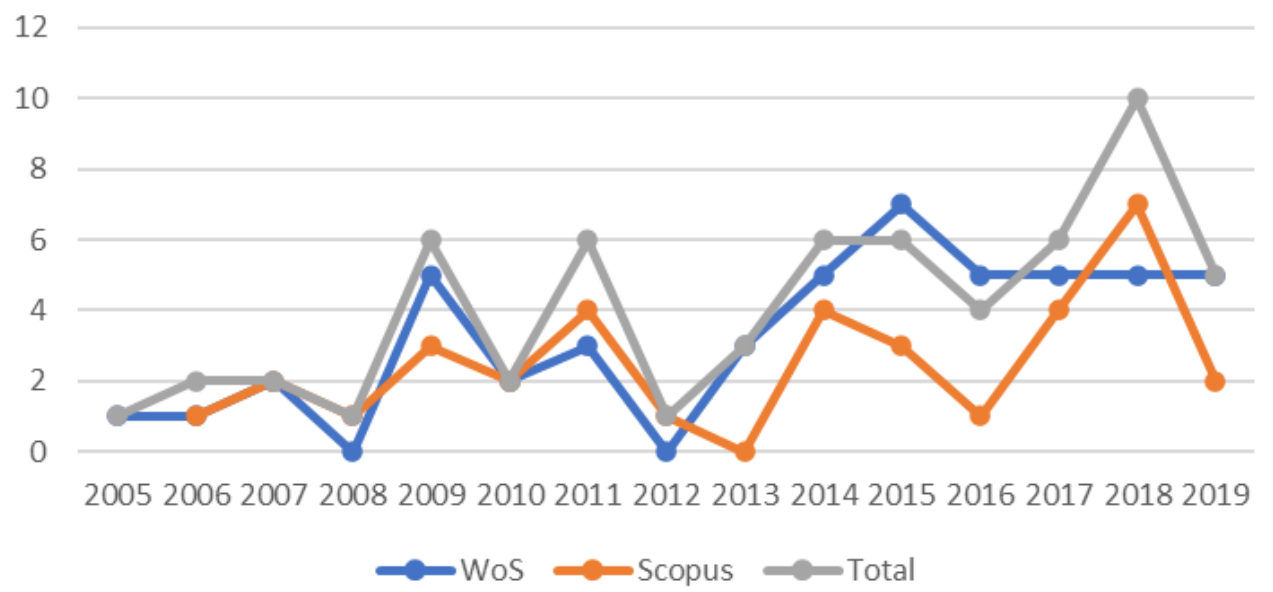

Figure 1. Evolution of published papers. 
We found 425 keywords. The 20 most common keyword are "Dementia", "aged", "Cognitive stimulation", "Article", "Mild cognitive impairment", "human", "quality of life", "Cognition", "controlled study", "Alzheimer disease", "caregiver", "cognitive defect", "cognitive therapy", "Neurodegenerative diseases", "adult", "aging", "Alzheimer's disease", "Cognitive stimulation therapy", "Cognitive stimulations" and "technology".

In Figure 2, we can see the network visualization of the keywords, using VOSviewer - Visualizing scientific landscapes. We found three clusters:

- (C1) Alzheimer's disease, cognition, quality of life, technology and treatment.

- (C2) Cognitive impairment, cognitive stimulation, cognitive training and computer.

- (C3) Cognitive function, internet and mild cognitive impairment.

Table 2 shows the most frequent keywords for different periods: until 2009, 2009-2014 and 2014-2019.

The authors are from 20 different countries. The countries with the largest number of articles are: United Kingdom (15\%), Spain (12\%) and United States (10\%).
The network of co-authorship countries has high density and a small number of clusters suggesting being centered on some countries. There are only two clusters with more than two countries:

- (C1) France, Greece, Ireland, Italy, New Zealand and South Korea.

- (C2) Canada, Netherlands, and United Kingdom.

The development of the co-authorship country research collaboration in CCS and PWD is presented in the Figure 3 distributed by degree of centrality, using VOSviewer. It is a centered network around United Kingdom, Spain and United States, France and Italy, which have the highest number of links with other countries, co-authoring several articles and the biggest importance in the development of the field.

We find that there are 93 organizations: 12 of these organizations have more than 2 articles. The most productive organizations by the number of the articles in CCS and PWD for the all period (1999-2020) includes the Consiglio Nazionale delle Ricerche, Aristotle University of Thessaloniki, Ewha Womans University, Hospital Provincial de Zamora, OHSU School of Medicine, Oregon Health and Science University, Portland VA Medical

Table 1. Journals/conference information's.

\begin{tabular}{|c|c|c|c|c|c|c|c|}
\hline Journal/Conference & $\#$ & Country & $\begin{array}{c}\text { SJR } \\
2018\end{array}$ & $\begin{array}{c}\text { IF } \\
2018\end{array}$ & WoS Subject (category) & Quartil & $H$ Index \\
\hline $\begin{array}{l}\text { International Journal of } \\
\text { Geriatric Psychiatry }\end{array}$ & 3 & $\begin{array}{l}\text { United } \\
\text { Kingdom }\end{array}$ & 1.41 & 3.141 & $\begin{array}{l}\text { Medicine (Geriatrics and Gerontology; } \\
\text { Psychiatry and Mental Health) }\end{array}$ & Q1 & 116 \\
\hline Journal of Alzheimer's Disease & 3 & Netherlands & & 3.517 & $\begin{array}{c}\text { Neurosciences (Neuroscience \& } \\
\text { Behavior; Neurosciences \& Behavior) }\end{array}$ & & \\
\hline $\begin{array}{l}\text { ACM International Conference } \\
\text { Proceeding Series }\end{array}$ & 2 & United States & 0.17 & & & & 98 \\
\hline Aging and Mental Health & 2 & $\begin{array}{l}\text { United } \\
\text { Kingdom }\end{array}$ & 1.23 & 2.956 & $\begin{array}{l}\text { Medicine (Geriatrics and Gerontology; } \\
\text { Psychiatry and Mental Health) } \\
\text { Nursing (Gerontology; } \\
\text { Psychiatric Mental Health) }\end{array}$ & Q1 & 74 \\
\hline $\begin{array}{l}\text { Alzheimer's and Dementia: Translational } \\
\text { Research and Clinical Interventions }\end{array}$ & 2 & United States & 1.5 & & $\begin{array}{c}\text { Medicine } \\
\text { (Neurology (clinical); } \\
\text { Psychiatry and Mental Health) }\end{array}$ & Q1 & 13 \\
\hline Clinical Interventions in Aging & 2 & New Zealand & 1 & 2.585 & $\begin{array}{l}\text { Medicine (Geriatrics and Gerontology) } \\
\text { Medicine (miscellaneous) }\end{array}$ & Q2; Q1 & 59 \\
\hline $\begin{array}{l}\text { Cochrane Database of } \\
\text { Systematic Reviews }\end{array}$ & 2 & United States & 1.61 & 7,755 & $\begin{array}{l}\text { Medicine (Medicine (miscellaneous); } \\
\text { Pharmacology (medical)) }\end{array}$ & Q1 & 244 \\
\hline $\begin{array}{l}\text { Journal of the American } \\
\text { Geriatrics Society }\end{array}$ & 2 & $\begin{array}{l}\text { United } \\
\text { Kingdom }\end{array}$ & 2.13 & 4.113 & $\begin{array}{l}\text { Medicine } \\
\text { Geriatrics and Gerontology }\end{array}$ & Q1 & 208 \\
\hline $\begin{array}{l}\text { Lecture Notes of the Institute for } \\
\text { Computer Sciences, Social-Informatics } \\
\text { and Telecommunications Engineering }\end{array}$ & 2 & Germany & 0.15 & & $\begin{array}{c}\text { Computer Science } \\
\text { (Computer Networks and Communications) }\end{array}$ & Q4 & 36 \\
\hline
\end{tabular}

SJR: Scientific Journal Rankings; IF: impact factor. 


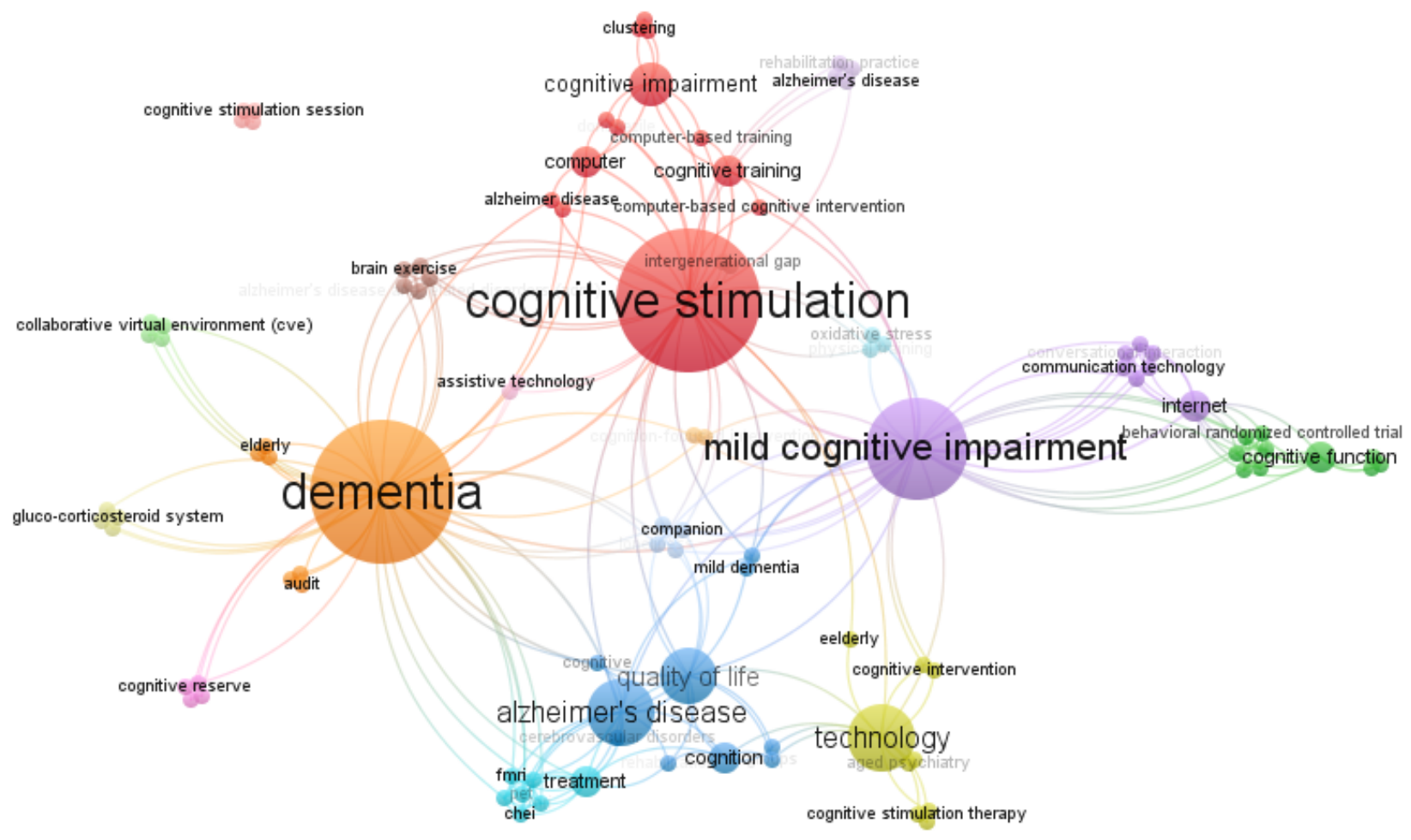

Figure 2. Network visualization, keywords.

Center, Universidad Autónoma de Baja California, Universidad de Salamanca, University of Hull, University of Melbourne and University of Michigan - Ann Arbor.

Because we didn't use the language exclusion criteria, we can now see that English is used in $89 \%$ of the articles. The other languages are Spanish (6\%), French (3\%) and Korean (3\%).

The affiliation of the most cited documents' author is AP-HP Assistance Publique - Hopitaux de Paris (Paris, France), followed by Université Paris Descartes (Paris, France). The next table (Table 3) list the most cited author affiliation.

According to Chen ${ }^{45}$ the most cited papers give historical perspective on scientific progress and reveal recognition of scientific advancement. As usual in the literature, older papers receive more citations than recent one, given the time length of knowledge diffusion. Curiously, the majority of top cited articles belong to a more recent period, and the most cited paper was published in 2010.

The most cited article, with 50 citations, was the Faucounau et al. ${ }^{36}$ with the title "Cognitive intervention programmes on patients affected by mild cognitive impairment: a promising intervention tool for MCI?". In this article, they found that though both traditional and computer-based cognitive intervention programs seem to be effective, the computer-based ones present more advantages, namely, the teams that work with patients with cognitive impairment could individualize the program tailored to the patient's neuropsychological pattern and needs; the computer-based cognitive intervention programs allow the user to make an immediate objective comparison with data collected earlier and also help in setting up a systematic training plan by providing instant value-free feedback and enable this tool offer a possibility of a widescale dissemination. In a paper with 44 citations, Viola et al. ${ }^{38}$ reported that they implemented a multidisciplinary rehabilitation program on cognition, quality of life, and neuropsychiatry symptoms in patients with mild AD. The group sessions were provided by a multiprofessional team and included computer-assisted cognitive stimulation, memory training, expressive activities, physiotherapy, and physical training. They found that this multimodal rehabilitation program was associated with cognitive stability and significant improvements in the quality of life for Alzheimer's patients. Recently, in 2017, in a paper with 33 citations, García-Casal et al. ${ }^{16}$ considered that computer-based cognitive interventions have moderate effects in cognition in PWD. However, they led to superior results compared to non-computer-based interventions in cognition. Another paper (with 27 citations), developed 
by Eckroth-Bucher and Siberski, ${ }^{35}$ found that blending computer-based with traditional cognitive stimulation activities showed promise in preserving cognitive function in older people. In 2014, in a paper, currently, with 33 citations, González-Palau et al. ${ }^{40}$ presented the

Table 2. Most frequent keywords for different periods.

\begin{tabular}{|c|c|c|}
\hline$<2009$ & 2010-2014 & 2015-2019 \\
\hline Human & Dementia & Dementia \\
\hline Alzheimer Disease & Aged & Human \\
\hline Article & Human & Aged \\
\hline Dementia & Cognitive Stimulation & Cognition \\
\hline Donepezil & Female & Cognitive Stimulation \\
\hline Humans & Humans & $\begin{array}{l}\text { Cognitive } \\
\text { Stimulations }\end{array}$ \\
\hline Male & Male & Female \\
\hline $\begin{array}{c}\text { Single Photon } \\
\text { Emission Computer } \\
\text { Tomography }\end{array}$ & $\begin{array}{l}\text { Mild Cognitive } \\
\text { Impairment }\end{array}$ & Male \\
\hline Adult & Alzheimer's Disease & $\begin{array}{l}\text { Mild Cognitive } \\
\text { Impairment }\end{array}$ \\
\hline Aged & $\begin{array}{l}\text { Neurodegenerative } \\
\text { Diseases }\end{array}$ & Article \\
\hline Aged, 80 And Over & Quality Of Life & Cognitive Therapy \\
\hline Alzheimer's Disease & Aged, 80 And Over & Controlled Study \\
\hline Cognition & Aging & Humans \\
\hline Cognitive Defect & Article & $\begin{array}{l}\text { Neurodegenerative } \\
\text { Diseases }\end{array}$ \\
\hline Cognitive Therapy & Cognition Disorders & Very Elderly \\
\hline Female & Controlled Study & Aged, 80 And Over \\
\hline Galantamine & Treatment Outcome & Cognitive Defect \\
\hline Major Clinical Study & Alzheimer Disease & $\begin{array}{c}\text { Computer Assisted } \\
\text { Therapy }\end{array}$ \\
\hline Neuroimaging & Cognition & $\begin{array}{l}\text { Human Computer } \\
\text { Interaction }\end{array}$ \\
\hline $\begin{array}{l}\text { Nuclear Magnetic } \\
\text { Resonance Imaging }\end{array}$ & Cognitive Defect & Major Clinical Study \\
\hline $\begin{array}{l}\text { Positron Emission } \\
\text { Tomography }\end{array}$ & Cognitive Impairment & Quality Of Life \\
\hline Priority Journal & Cognitive Therapy & Caregiver \\
\hline \multirow[t]{9}{*}{ Risk Factors } & Cognitive Training & $\begin{array}{c}\text { Cognitive Stimulation } \\
\text { Therapy }\end{array}$ \\
\hline & Computer Science & $\begin{array}{l}\text { Mild Cognitive } \\
\text { Impairments }\end{array}$ \\
\hline & Health Care & Patient Treatment \\
\hline & Internet & Pilot Study \\
\hline & Physical Activity & Priority Journal \\
\hline & Review & Psychology \\
\hline & Technology & Technology \\
\hline & \multicolumn{2}{|l|}{ Ubiquitous Computing } \\
\hline & Very Elderly & \\
\hline
\end{tabular}

results of a study using the newly integrated platform (The Long Lasting Memories program) which combined cognitive exercises with physical activity within the context of advanced technologies. This study indicated this program was a promising solution for older adults with and without cognitive impairment, maintaining their well-being with few professional and technical requirements. Breton et al. ${ }^{22}$ reported a tool focuses on therapeutic aspects of both cognitive and physical stimulation of the older people, that is, it improves the memory by performing mental activities and physical exercise at the same time. Preliminary tests have shown an increase in the users' motivation while using the tool forgetting that it focuses on the CS. Using another approach to the use of CCS and PWD, Dodge et al. ${ }^{24}$ examined the feasibility of a randomized controlled trial to assess conversation-based cognitive stimulation through personal computers, webcams, and a user-friendly interactive Internet interface and they found that daily conversations by way of user-friendly Internet communication programs demonstrated high adherence. They concluded that the increasing daily social contacts through communication technologies

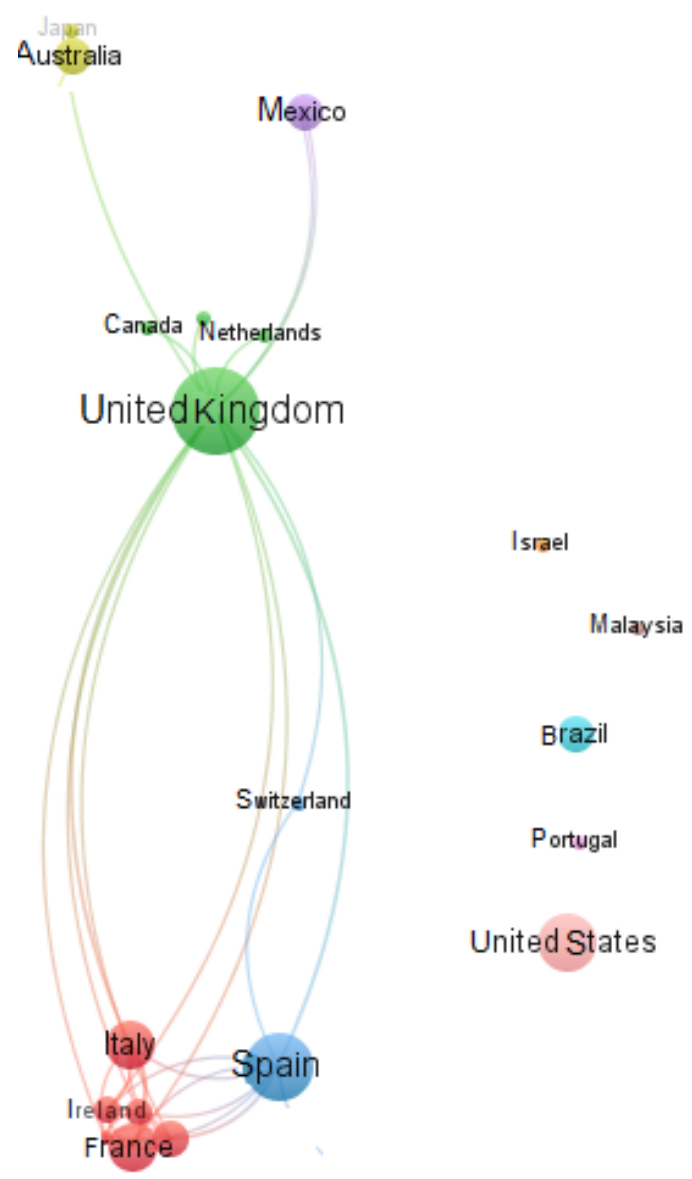

Figure 3. Network visualization, countries. 
Table 3. Most cited documents' author affiliation.

\begin{tabular}{|c|c|c|}
\hline & Author & Affiliation \\
\hline \multirow[t]{5}{*}{1} & Faucounau $^{36}$ & AP-HP Assistance Publique - Hopitaux de Paris, Paris, France \\
\hline & $\mathrm{Wu}^{36}$ & Université Paris Descartes, Paris, France \\
\hline & Boulay $^{36}$ & Université Paris Descartes, Paris, France \\
\hline & Rotrou $^{36}$ & Université Paris Descartes, Paris, France \\
\hline & Rigaud $^{36}$ & Université Paris Descartes, Paris, France \\
\hline \multirow[t]{19}{*}{2} & Viola ${ }^{38}$ & Department and Institute of Psychiatry, Universidade de Sao Paulo, SP, Brazil \\
\hline & Nunes $^{38}$ & Department and Institute of Psychiatry, Universidade de Sao Paulo, SP, Brazil \\
\hline & Yassuda $^{38}$ & School of Arts, Sciences and Humanities, Universidade de São Paulo, SP, Brazil \\
\hline & Aprahamian $^{38}$ & Department and Institute of Psychiatry, Universidade de Sao Paulo, SP, Brazil \\
\hline & Santos $^{38}$ & Hospital da Faculdade de Medicina da Universidade de São Paulo, SP, Brazil \\
\hline & Santos 38 & Department and Institute of Psychiatry, Universidade de Sao Paulo, SP, Brazil \\
\hline & Brum $^{38}$ & Department and Institute of Psychiatry, Universidade de Sao Paulo, SP, Brazil \\
\hline & Borges $^{38}$ & Department and Institute of Psychiatry, Universidade de Sao Paulo, SP, Brazil \\
\hline & Oliveira $^{38}$ & Department and Institute of Psychiatry, Universidade de Sao Paulo, SP, Brazil \\
\hline & Chaves $^{38}$ & Department and Institute of Psychiatry, Universidade de Sao Paulo, SP, Brazil \\
\hline & Ciasca $^{38}$ & Department and Institute of Psychiatry, Universidade de Sao Paulo, SP, Brazil \\
\hline & Ferreira $^{38}$ & Department and Institute of Psychiatry, Universidade de Sao Paulo, SP, Brazil \\
\hline & de Paula ${ }^{38}$ & Department and Institute of Psychiatry, Universidade de Sao Paulo, SP, Brazil \\
\hline & Takeda $^{38}$ & Department and Institute of Psychiatry, Universidade de São Paulo, SP, Brazil \\
\hline & Mirandez $^{38}$ & Department and Institute of Psychiatry, Universidade de São Paulo, SP, Brazil \\
\hline & Watari38 & Department and Institute of Psychiatry, Universidade de São Paulo, SP, Brazil \\
\hline & Falcão $0^{38}$ & School of Arts, Sciences and Humanities, Universidade de São Paulo, SP, Brazil \\
\hline & Cachioni38 & School of Arts, Sciences and Humanities, Universidade de São Paulo, SP, Brazil \\
\hline & Forlenza $^{38}$ & Department and Institute of Psychiatry, Universidade de SP, SP, Brazil \\
\hline \multirow[t]{6}{*}{3} & García-Casal' $^{16}$ & Universidad de Salamanca, Salamanca, Spain \\
\hline & Loizeau $^{16}$ & Center for Gerontology, University of Zurich, Zurich, Switzerland \\
\hline & Csipke $^{16}$ & University College London, Institute of Mental Health, London, UK \\
\hline & Franco-Martín ${ }^{16}$ & Hospital Universitario Río Hortega, Valladolid, Spain \\
\hline & Perea-Bartolomé ${ }^{16}$ & Universidad de Salamanca, Salamanca, Spain \\
\hline & Orrell ${ }^{16}$ & University of Nottingham, Nottingham, United Kingdom \\
\hline \multirow[t]{7}{*}{4} & González-Palau ${ }^{40}$ & Fundación Intras, Valladolid, Spain \\
\hline & Franco $^{40}$ & Hospital Zamora, Zamora, Spain \\
\hline & Bamidis $^{40}$ & Greek Aerospace Medical Association and Space Research, Greece \\
\hline & Losada $^{40}$ & Fundación Intras, Valladolid, Spain \\
\hline & Parra $^{40}$ & Fundación Intras, Valladolid, Spain \\
\hline & Papageorgiou ${ }^{40}$ & University of Athens Medical School, Athens, Greece \\
\hline & Vivas $^{40}$ & The University of Sheffield International Faculty, Sheffield, Greece \\
\hline 5 & Venneri ${ }^{57}$ & University of Hull, Hull, United Kingdom \\
\hline \multirow[t]{2}{*}{6} & ${\text { Eckroth-Bucher }{ }^{35}}^{3}$ & Bloomsburg University, Bloomsburg, United States \\
\hline & Siberskij ${ }^{35}$ & College Misericordia, Dallas, United States \\
\hline \multirow[t]{3}{*}{7} & Breton $^{22}$ & Universidad de Deusto, Bilbao, Spain \\
\hline & Zapirain $^{22}$ & Universidad de Deusto, Bilbao, Spain \\
\hline & Zorrilla22 & Universidad de Deusto, Bilbao, Spain \\
\hline \multirow[t]{8}{*}{8} & Dodge $^{24}$ & University of Michigan, Ann Arbor, Ann Arbor, United States \\
\hline & Zhu $^{24}$ & University of Michigan, Ann Arbor, Ann Arbor, United States \\
\hline & Mattek $^{24}$ & Oregon Health and Science University, Portland, United States \\
\hline & Bowman $^{24}$ & Oregon Health and Science University, Portland, United States \\
\hline & Ybarra $^{24}$ & University of Michigan, Ann Arbor, Ann Arbor, United States \\
\hline & Wild $^{24}$ & Oregon Health and Science University, Portland, United States \\
\hline & Loewenstein $^{24}$ & University of Florida, Gainesville, United States \\
\hline & Kaye $^{24}$ & Oregon Health and Science University, Portland, United States \\
\hline \multirow[t]{3}{*}{9} & Westphal $^{37}$ & University of Melbourne, Parkville, Australia \\
\hline & Dingjan $^{37}$ & University of Melbourne, Parkville, Australia \\
\hline & Attoe $^{37}$ & University of Melbourne, Parkville, Australia \\
\hline
\end{tabular}


could offer cost-effective home-based prevention methods. In Table 3, we can also see the reference to the paper by Westphal et al. ${ }^{37}$ with 14 citations. They identified and reviewed the latest research in the use of low and high technology in the areas of mood disorders, psychosis, normal ageing, mild cognitive impairment and dementia, and they found that research in the use of low and high technology in late-life mental disorders continued to evolve in its scope and innovation. These authors also considered that to make progress in accessibility and acceptability of technology, involvement of stakeholders and users in the design and application, as well as the examination of cost-effectiveness and robust methodologically designed studies, is necessary.

The Table 4 lists the affiliations of the authors of the most cited articles. Some of the most productive institutions involved in CCS and PWD are Department and Institute of Psychiatry, Universidade de São Paulo, São Paulo, Brazil and Université Paris Descartes, Paris, France.

In the Table 5, we list the information of the ten most cited papers: author, year, title, source, keywords and number of citations (Citats).

The country affiliation with the most cited authors is the United States (25\%), followed by Spain (21\%), Greece (13\%), United Kingdom (13\%), Brazil (12\%), France (8\%), Switzerland (4\%) and Australia (4\%).

We found five keyword clusters (as we can see in Figure 3):

- (C1) Communication technology, conversational interactivity, internet, mild cognitive impairment, Oregon Centre for Aging, prevention study, randomized controlled clinic, and social engagement.

- (C2) Cognitive impairment, cognitive stimulation, cognitive training, computer-based cognitive inter and computer-based training.

- (C3) Alzheimer's disease, cognition, quality of life, rehabilitation and treatment.

- (C4) Dementia, elderly, Kinect and windows.

- (C5) Alzheimer's disease, cognitive rehabilitation and therapy.

\section{DISCUSSION}

The purpose of this paper was to analyze the scientific production in CCS and PWD in journals indexed in Clarivate Analytics' Web of Science and Elsevier's Scopus since 2000. This work was the first bibliometric review study and very useful about the exploration of the literature CCS and PWD or people with MCI from WoS and Scopus databases, and has outlined the evolutionary trajectory of the collective knowledge over the past 21 years and highlighted the areas of active pursuit.
Let us answer the research questions. The bibliometric questions considered are:

\section{Q1: When were the articles published?}

The average number of articles is 4 per year. The year with the greatest number of articles is 2018 (10). The curves of publications have an increasing trend until 2018 in both datasets, explaining the progress of scientific literature in this field of research. In 2019, there has been a decrease in published papers.

\section{Q2: Where were the articles published?}

There are 50 sources of publications: only two journals have three publications (International Journal of Geriatric Psychiatry and Journal of Alzheimer's Disease) and seven others have two publications (one of these is

Table 4. Affiliation author, most cited articles.

\begin{tabular}{ll}
\hline Affiliation & $\mathbf{n}$ \\
\hline $\begin{array}{l}\text { Department and Institute of Psychiatry, } \\
\text { Universidade de São Paulo, São Paulo, Brazil }\end{array}$ & 15 \\
\hline Universite Paris Descartes, Paris, France & 4 \\
\hline Fundación Intras, Valladolid, Spain & 3 \\
\hline Oregon Health and Science University, Portland, United States & 3 \\
\hline School of Arts, Sciences and Humanities, & 3 \\
\hline Universidade de São Paulo, São Paulo, Brazil & 3 \\
\hline Universidad de Deusto, Bilbao, Spain & 3 \\
\hline University of Melbourne, Parkville, Australia & 3 \\
\hline University of Michigan, Ann Arbor, Ann Arbor, United States & 2 \\
\hline Universidad de Salamanca, Salamanca, Spain & 1 \\
\hline AP-HP Assistance Publique - Hopitaux de Paris, Paris, France & 1 \\
\hline Bloomsburg University, Bloomsburg, United States & 1 \\
\hline Center for Gerontology, University of Zurich, Zurich, Switzerland & 1 \\
\hline Hospital das Clínicas da Faculdade de Medicina da & 1 \\
\hline Universidade de São Paulo, S. Paulo, Brazil & 1 \\
\hline College Misericordia, Dallas, United States & 1 \\
\hline Greek Aerospace Medical Association and & 1 \\
\hline Space Research, Thessaloniki, Greece & 1 \\
\hline Hospital Universitario Río Hortega, Valladolid, Spain & 1 \\
\hline Hospital Zamora, Zamora, Spain & 1 \\
\hline Oregon Health and Science University, Portland, United States & 1 \\
\hline The University of Sheffield International Faculty, Sheffield, Greece & 1 \\
\hline University College London, Institute of Mental & 1 \\
\hline University of Athens Medical School, Athens, Greece & 1 \\
\hline University of Nottingham, Nottingham, United Kingdom & 1 Hull, Hull, United Kingdom \\
\hline
\end{tabular}


ACM International Conference Proceeding Series), most of these are from the first quartile. With more than two publications: three journals are from United Kingdom and three from United States.

\section{Q3: What is the focus of the articles? Has it evolved over the years?}

We found 425 keywords. The 20 most common keyword are "Dementia", "aged", "Cognitive stimulation", "Article", "Mild cognitive impairment", "human", "quality of life", "Cognition”, "controlled study", "Alzheimer disease", "caregiver", "cognitive defect”, "cognitive therapy", "Neurodegenerative diseases", "adult", "aging",
"Alzheimer's disease", "Cognitive stimulation therapy", "Cognitive stimulations" and "technology". We found three clusters:

- (C1) Alzheimer's disease, cognition, quality of life, technology, and treatment.

- (C2) Cognitive impairment, cognitive stimulation, cognitive training, and computer.

- (C3) Cognitive function, internet, and mild cognitive impairment.

The most frequent keywords until 2009 were "Human", "Alzheimer Disease", "Article", "Dementia", "Donepezil" and "Humans"; from 2010-2014, were

Table 5. Most cited papers.

\begin{tabular}{|c|c|c|c|c|c|}
\hline Author & Year & Title & Source & Keywords & Citats \\
\hline $\begin{array}{l}\text { Faucounau } \\
\text { et al. }^{36}\end{array}$ & 2010 & $\begin{array}{l}\text { Cognitive intervention programmes on patients } \\
\text { affected by mild cognitive impairment: } \mathrm{A} \\
\text { promising intervention tool for } \mathrm{MCl} \text { ? }\end{array}$ & $\begin{array}{l}\text { Journal of Nutrition, } \\
\text { Health and Aging. } \\
2010 ; 14(1): 31-5\end{array}$ & $\begin{array}{l}\text { Cognitive stimulation; Cognitive } \\
\text { training; Computer-based } \\
\text { cognitive intervention; Mild } \\
\text { cognitive impairment }\end{array}$ & 50 \\
\hline Viola et al ${ }^{38}$ & 2011 & $\begin{array}{l}\text { Effects of a multidisciplinar cognitive } \\
\text { rehabilitation program for patients } \\
\text { with mild Alzheimer's disease }\end{array}$ & $\begin{array}{l}\text { Clinics. 2011;66(8):1395- } \\
400\end{array}$ & $\begin{array}{l}\text { Alzheimer's disease; } \\
\text { Cognition; Quality of life; } \\
\text { Rehabilitation; Treatment }\end{array}$ & 44 \\
\hline $\begin{array}{l}\text { García-Casal } \\
\text { et al. }{ }^{16}\end{array}$ & 2017 & $\begin{array}{l}\text { Computer-based cognitive interventions for } \\
\text { people living with dementia: a systematic } \\
\text { literature review and meta-analysis }\end{array}$ & $\begin{array}{l}\text { Aging and Mental Health. } \\
\text { 2017;21(5):454-67 }\end{array}$ & $\begin{array}{l}\text { Alzheimer disease; Cognitive } \\
\text { rehabilitation; cognitive } \\
\text { stimulation; computer; dementia }\end{array}$ & 33 \\
\hline $\begin{array}{l}\text { González- } \\
\text { Palau et al. }{ }^{40}\end{array}$ & 2014 & $\begin{array}{l}\text { The effects of a computer-based cognitive } \\
\text { and physical training program in a healthy } \\
\text { and mildly cognitive impaired aging sample }\end{array}$ & $\begin{array}{l}\text { Aging and Mental Health. } \\
\text { 2013;18(7):838-46 }\end{array}$ & $\begin{array}{c}\text { Alzheimer's disease; } \\
\text { cognitive stimulation; mild } \\
\text { cognitive impairment; mild } \\
\text { dementia; physical activity }\end{array}$ & 33 \\
\hline Venneri $^{57}$ & 2007 & Imaging treatment effects in Alzheimer's disease & $\begin{array}{c}\text { Magnetic } \\
\text { Resonance Imaging. } \\
2007 ; 25(6): 953-68\end{array}$ & & 31 \\
\hline $\begin{array}{l}\text { Eckroth-Bucher } \\
\text { and Siberski }{ }^{35}\end{array}$ & 2009 & $\begin{array}{l}\text { Preserving cognition through an integrated } \\
\text { cognitive stimulation and training program }\end{array}$ & $\begin{array}{l}\text { American Journal of } \\
\text { Alzheimer's Disease } \\
\text { and other Dementias. } \\
\text { 2009;24(3):234-45 }\end{array}$ & $\begin{array}{l}\text { Cognitive impairment; Cognitive } \\
\text { stimulation; Cognitive training; } \\
\text { Computer-based training }\end{array}$ & 27 \\
\hline Breton et al. ${ }^{22}$ & 2012 & $\begin{array}{l}\text { KiMentia: Kinect based tool to help cognitive } \\
\text { stimulation for individuals with dementia }\end{array}$ & $\begin{array}{l}2012 \text { IEEE Proceedings } \\
\text { of the 14th International } \\
\text { Conference on e-Health } \\
\text { Networking, Applications } \\
\text { and Services (Healthcom). } \\
\text { IEEE; 2012. p. 325-8 }\end{array}$ & $\begin{array}{l}\text { Dementia; elderly; } \\
\text { Kinect; Windows }\end{array}$ & 21 \\
\hline Dodge et al. ${ }^{24}$ & 2015 & $\begin{array}{l}\text { Web-enabled conversational interactions as a } \\
\text { method to improve cognitive functions: Results } \\
\text { of a } 6 \text {-week randomized controlled trial }\end{array}$ & $\begin{array}{l}\text { Alzheimer's \& Dementia: } \\
\text { Translational Research } \\
\text { \& Clinical Interventions. } \\
\text { 2015;1(1):1-12 }\end{array}$ & $\begin{array}{l}\text { Communication technology; } \\
\text { Conversational interaction; } \\
\text { Internet; Mild cognitive } \\
\text { impairment; Oregon Center } \\
\text { for Aging and Technology } \\
\text { (ORCATECH); Prevention study; } \\
\text { Randomized controlled clinical } \\
\text { trial; Social engagement }\end{array}$ & 21 \\
\hline Westphal et al. ${ }^{37}$ & 2010 & $\begin{array}{l}\text { What can low and high technologies } \\
\text { do for late-life mental disorders? }\end{array}$ & $\begin{array}{l}\text { Current Opinion } \\
\text { in Psychiatry. } \\
2010 ; 23(6): 510-5\end{array}$ & $\begin{array}{c}\text { Aged psychiatry; } \\
\text { technology; therapy }\end{array}$ & 14 \\
\hline
\end{tabular}


"Dementia", "Aged”, "Human", "Cognitive Stimulation", "Female" and "Humans"; from 2015-2019, were "Dementia”, "Human", "Aged", "Cognition", "Cognitive Stimulation" and "Cognitive Stimulations".

\section{Q4: Who publishes on the subject? Where do researchers who are interested in PWD work? What country do they live in?}

There are 320 authors. Only three of these 320 wrote three articles: Dodge, Hiroko Hayama (University of Michigan, Ann Arbor, United States), Lenoir, Hermine (Université Paris Descartes, Paris, France) and Meza-Kubo, Victoria (Universidad Autónoma de Baja California, Ensenada, Mexico). There are authors from 20 countries. The countries with the largest number of articles are: United Kingdom (15\%), Spain (12\%) and United States (10\%).

The large projected increase in the number of people with dementia makes finding a treatment to slow or stop dementia as soon as possible essential. The investigations try to find solutions regarding how to deal with dementia in countries with many PWD. As the number of $\mathrm{AD}$ cases rises rapidly in an aging global population, the need to understand this puzzling disease is growing and the number of researches is growing in countries like the United Kingdom, Spain and United States.

According to Alzheimer Europe, ${ }^{46}$ examining the population data of the United Kingdom, there is an increase in population for the period 2018 and 2025, with a significant increase in the numbers of people aged over 65 , and, in particular, the over 85 age range, which more than doubles between this period. It should be noted that PWD will represent $2.67 \%$ of the overall population in 2050 compared to $1.56 \%$ in 2018 . Villarejo-Galende et al. ${ }^{47}$ performed a literature review of the published evidence and they found that in Spain most population studies of patients older than 65 report prevalence rates ranging from 4 to $9 \%$. Prevalence of dementia and $A D$ is higher in women for nearly every age group. $\mathrm{AD}$ is the most common cause of dementia (50-70\% of all cases). According to the Alzheimer Association, ${ }^{1}$ millions of Americans have Alzheimer's or other dementias and, as the size and proportion of the U.S. population age 65 and older continue to increase, the number of Americans with Alzheimer's or other dementias will grow. The Alzheimer Association ${ }^{1}$ considers that this number will escalate rapidly in coming years, as the population of Americans age. Thus, 65 and older is projected to grow from 55 million in 2019 to 88 million by 2050 .

\section{Q5: What are the most cited articles?}

The most cited papers give historical perspective on scientific progress and reveal recognition of scientific advancement. For this classification, we use the numbers presented in the Scopus database. We found that the positions coincided with the WoS database. We observed that the most cited paper was the Faucounau et al., ${ }^{36}$ who found that, though both traditional and computer-based cognitive intervention programs seem to be effective, the computer-based ones have more advantages. This paper is in line with the review published studies on CCS and PWD published by Djabelkhir et al. ${ }^{15}$ who considered that computerized cognitive training programs may be used as a practical and valuable tool in clinic to improve cognitive status. However, the most cited paper contrasted with another paper by Gates et al. ${ }^{48}$ that evaluated the effects of at least 12 weeks of computerized cognitive training on maintaining or improving cognitive function and preventing dementia in people with MCI. They concluded that currently available evidence did not allow them to determine whether or not computerized cognitive training will prevent clinical dementia or improve or maintain cognitive function in those who already have evidence of cognitive impairment. In an systematic review article, Irazoki et al. ${ }^{49}$ studies of computerized cognitive interventions for PWD and cognitive impairment were included if they clearly described objectives, users and functioning. On the overall, the programs were aimed at people with different clinical conditions, able to create specific treatments and personalized training, optimized for portable devices, and user-friendly. These authors found that the selected programs differed from each other in terms of objectives, usage mode and characteristics, even if they were used for the same purposes, and they concluded that more information about the features and context of use was needed, as well as more clinical studies, to be able to compare among computerized cognitive programs. This review work was of great importance because the information obtained in the review may be relevant to distinguish programs and select the one that best suits each user.

Some of the most productive institutions involved in CCS and PWD are Department and Institute of Psychiatry, Universidade de São Paulo, São Paulo, Brazil and Université Paris Descartes, Paris, France. The country with the most cited authors is the United States, followed by Spain. The biggest keyword cluster from the most cited articles is communication technology, conversational interactivity, internet, mild cognitive impairment, Oregon Centre for Aging, prevention study, randomized controlled clinic and social engagement.

The progressive increase in the number of scientific papers in CCS and PWD until 2018 likely to combine the effects of a number of factors: the aging of the 
population, ${ }^{50,51}$ the risk of dementia grows exponentially with age, ${ }^{1,2,52}$ an increase in the global prevalence of dementia; ${ }^{46,53,54}$ an increase in awareness of dementia as a serious public health problem, ${ }^{55,56}$ non-pharmacological interventions in combination with pharmacotherapies have been considered as the best approach in management of PWD, ${ }^{56}$ and the computer use in its different types has proven to be an ally to those who want to detect and mitigate this disease. ${ }^{15}$

We consider that determining the effectiveness of non-pharmacologic therapies can be difficult because of the large number of existing therapies (including CCS and PWD), the diversity of therapeutic aims, the diverse dementia stages, the diverse types of dementia and the lack of a standard method for carrying out any non-pharmacological therapy.

The search terms identified 61 papers related to the use of computers applied to cognitive stimulation and PWD or people with MCI. We found that there was an increasing trend in the paper publication in CCS and PWD until 2018 in WoS and Scopus, explaining the progress of scientific literature in this field of research. In the last year, we noted that there has been a decrease in published papers. The International Journal of Geriatric Psychiatry and Journal of Alzheimer's Disease had the largest number of publications in CCS and PWD between 1999 and 2000. Major research' countries are United Kingdom, Spain and United States, and Aristotle University of Thessaloniki (Greece) is the affiliation author with most cited articles. The most productive organizations in the number of the articles in CCS and PWD for the all period (1999-2020) were the Consiglio Nazionale delle Ricerche. Dodge, Lenoir and Meza-Kubo published the largest number of papers. The most cited paper was Faucounau et $a l .{ }^{36}$ In this paper, the authors clearly emphasized the advantages of using the computer-based cognitive intervention, which have more advantages compared to traditional cognitive intervention: intervention tailored to the patient's neuropsychological pattern and needs; to make an immediate objective comparison with data collected earlier, and thus help in setting up a systematic training.

The 20 most common keyword were "Dementia", "aged", "Cognitive stimulation", "Article", "Mild cognitive impairment", "human", "quality of life", "Cognition", "controlled study", "Alzheimer disease”, "caregiver", "cognitive defect", "cognitive therapy", "Neurodegenerative diseases", "adult", "aging”, "Alzheimer's disease", "Cognitive stimulation therapy", "Cognitive stimulations" and "technology'. The limitations of this study are related with the inclusion of studies in English only, introducing language bias.

The findings in these papers were analyzed to find recommendations for future work in this area. We concluded that the CCS has been increasingly used as an intervention tool for PWD and MCI and there still seems to be a possibility for evolution in good quality publications. Further research is needed on CCS for PWD using a standard method for carrying out non-pharmacological intervention.

Authors' contributions. SRS and MS: conceptualization, data curation, formal analysis, investigation, methodology, project administration, resources, software, supervision, validation, visualization, writing — original draft, writing — review \& editing.

\section{REFERENCES}

1. Alzheimer's Association. 2019 Alzheimer's disease facts and figures. Alzheimers Dement. 2019;15(3):321-87. https://doi.org/10.1016/j. jalz.2019.01.010

2. Sobral M, Pestana MH, Paúl C. Measures of cognitive reserve in Alzheimer's disease. Trends Psychiatry Psychother. 2014;36(3):160-8. https:// doi.org/10.1590/2237-6089-2014-0012

3. Petersen RC, Caracciolo B, Brayne C, Gauthier S, Jelic V, Fratiglioni L. Mild cognitive impairment: a concept in evolution. J Intern Med. 2014;275(3):214-28. https://doi.org/10.1111/joim.12190

4. Greenwood CE, Parrott MD. Nutrition as a component of dementia risk reduction strategies. Healthc Manage Forum. 2017;30(1):40-5. https:// doi.org/10.1177/0840470416662885

5. Pestana MH, Sobral M. Alzheimer's disease research: a network science approach. Int J Multivar Anal. 2018;1(3):201-17. https://doi.org/10.1504/ IJMDA.2018.091838

6. Wilson RS, Mendes de Leon CF, Barnes LL, Schneider JA, Bienias JL, Evans DA, et al. Participation in cognitively stimulating activities and risk of incident Alzheimer disease, JAMA. 2002;287(6):742-8. https://doi. org/10.1001/jama.287.6.742

7. Aguirre E, Hoare Z, Streater A, Spector A, Woods B, Hoe J, et al. Cognitive stimulation therapy (CST) for people with dementia - who benefits most? Int J Geriatr Psychiatry. 2013;28(3):284-90. https://doi.org/10.1002/ gps.3823

8. De-Leon J, Llanero M. Computer-based cognitive training and donepezile: Combined therapy effects in cognitive impairment. Mapfre Med. 2007;18(1):25-33.

9. Olazarán J, Reisberg B, Clare L, Cruz I, Peña-Casanova J, Del Ser T, et al. Nonpharmacological therapies in Alzheimer's disease: a systematic review of efficacy. Dement Geriatr Cogn Disord. 2010;30(2):161-78. https://doi. org/10.1159/000316119

10. Woods B, Aguirre E, Spector A, Orrell M. Cognitive stimulation to improve cognitive functioning in people with dementia. Cochrane Database Syst Rev. 2012;(2):CD005562. https://doi.org/10.1002/14651858.CD005562. pub2 
11. Kim K, Han JW, So Y, Seo J, Kim YJ, Park JH, et al. Cognitive stimulation as a therapeutic modality for dementia: a meta-analysis. Psychiatry Investig. 2017;14(5):626-39. https://doi.org/10.4306/pi.2017.14.5.626

12. Meza-Kubo V, Gozales-Fraga JA, Moran AL, Tentori M. Augmenting cognitive stimulation activities in a nursing home through pervasive computing. 2009 Latin American Web Congress, Merida, Yucatan; 2009. p.8-15. https://doi: 10.1109/LA-WEB.2009.38

13. Piasek P, Irving K, Smeaton A. SenseCam intervention based on cognitive stimulation therapy framework for early-stage dementia. Proceedings of the 5th International Conference on Pervasive Computing Technologies for Healthcare (PervasiveHealth) and Workshop. Dublin; 2011. p.522-5. https://doi: 10.4108/icst.pervasivehealth.2011.246123

14. Maseda A, Millán-Calenti JC, Lorenzo-López L, Núñez-Naveira L. Efficacy of a computerized cognitive training application for older adults with and without memory impairments. Aging Clin Exp Res. 2013;25(4):411-19. https://doi.org/10.1007/s40520-013-0070-5

15. Djabelkhir L, Wu YH, Vidal JS, Cristancho-Lacroix V, Marlats F, Lenoir H, et al. Computerized cognitive stimulation and engagement programs in older adults with mild cognitive impairment: comparing feasibility, acceptability, and cognitive and psychosocial effects. Clin Interv Aging. 2017;12:196775. https://doi.org/10.2147/CIA.S145769

16. García-Casal JA, Loizeau A, Csipke E, Franco-Martín M, Perea-Bartolomé M, Orrell M. Computer-based cognitive interventions for people living with dementia: a systematic literature review and meta-analysis. Aging Ment Health. 2017;21(5):454-67. https://doi.org/10.1080/13607863.2015.11 32677

17. Booth A, Sutton A, Papaioannou D. Systematic approaches to a successful literature review. $2^{\text {nd }}$ ed. London: SAGE Publications Ltd; 2016.

18. Pritchard A. Statistical Bibliography or Bibliometrics. J Doc.1969; 25(4):348-49.

19. Moed HF. Citation analysis in research evaluation. Information Science and Knowledge Management. v. 9. Dordrecht: Springer; 2005. p.348.

20. Bojović S, Matić R, Popović Z. An overview of forestry journals in the period 2006-2010 as basis for ascertaining research trends. Scientometrics. 2014;98:1331-46. https://doi.org/10.1007/s11192-013-1171-9

21. Liu W, Gu M, Hu G, Profile of developments in biomass-based bioenergy research: a 20-year perspective. Scientometrics. 2014;99:507-21. https:// doi.org/ 0.1007/s11192-013-1152-z

22. Breton ZSDU, Zapirain BG, Zorrilla AM. KiMentia: Kinect based tool to help cognitive stimulation for individuals with dementia. In: 2012 IEEE Proceedings of the 14th International Conference on e-Health Networking, Applications and Services (Healthcom). IEEE; 2012. p. 325-8. https://doi. org/10.1109/HealthCom.2012.6379430

23. Tarnanas I, Tsolakis A, Tsolaki M. Assessing virtual reality environments as cognitive stimulation method for patients with $\mathrm{MCl}$. Stud Comput Intell. 2014;536:39-74. https://doi.org/10.1007/978-3-642-45432-5_4

24. Dodge HH, Zhu J, Mattek N, Bowman M, Ybarra O, Wild KV, et al. Web-enabled conversational interactions as a method to improve cognitive functions: Results of a 6-week randomized controlled trial. Alzheimers Dement (NY). 2015;1(1):1-12. https://doi.org/ 10.1016/j.trci.2015.01.001

25. Caroppo A, Leone A, Siciliano P, Sancarlo D, D'Onofrio G, Greco A, et al. Design and evaluation of an ICT platform for cognitive stimulation of Alzheimer's disease patients. In: Smart Objects and Technologies for Social Good - Proceedings of the 2nd International Conference, GOODTECHS 2016. v. 195 LNICST. Springer Verlag; 2017. p.106-15. (Lecture Notes of the Institute for Computer Sciences, Social-Informatics and Telecommunications Engineering, LNICST). https://doi.org/10.1007/978-3-319-61949-1_12

26. Arlati S, Greci L, Mondellini M, Zangiacomi A, Di Santo SG, Franchini F, et al. A virtual reality-based physical and cognitive training system aimed at preventing symptoms of dementia. In: Rahmani AM, TaheriNejad N, Perego P, editors. In: Wireless Mobile Communication and Healthcare. Proceedings of the 7th International Conference, MobiHealth 2017. Springer Verlag; 2018. p.117-125. (Lecture Notes of the Institute for Computer Sciences, Social-Informatics and Telecommunications Engineering, LNICST). https://doi.org/10.1007/978-3-319-98551-0_14

27. Bahar-Fuchs A, Martyr A, Goh AMY, Sabates J, Clare L. Cognitive training for people with mild to moderate dementia. Cochrane Database Syst Rev. 2019;3(3):CD013069. https://doi.org/10.1002/14651858.CD013069

28. Tarraga L, Boada M, Modinos G, Espinosa A, Diego A, Morera A, et al. A randomised pilot study to assess the efficacy of an interactive, multimedia tool of cognitive stimulation in Alzheimer's disease. J Neurol Neurosurg Psychiatry. 2006;77(10):1116-21. https://doi.org/10.1136/ jnnp.2005.086074

29. Moran AL, Meza-Kubo V. Towards a tele-assistance service for the cognitive stimulation of elders with cognitive decline. In: Proceedings of the International Conference on Ehealth, Telemedicine, and Social Medicine. Etelemed; 2009. p.160-5. https://doi.org/10.1109/eTELEMED.2009.26

30. Zelinski EM, Spina LM, Yaffe K, Ruff R, Kennison RF, Mahncke HW, et al. Improvement in memory with plasticity-based adaptive cognitive training: results of the 3-month follow-up. J Am Geriatr Soc. 2011;59(2):258-65. https://doi.org/10.1111/j.1532-5415.2010.03277.x

31. Pang GK-H, Kwong E. Considerations and design on apps for elderly with mild-to-moderate dementia. IEEE Computer Society; 2015. p. 34853 [accessed on Jun 20, 2020]. Available at: http://dblp.uni-trier.de/db/ conf/icoin/icoin2015.html\#PangK15.

32. Pham TD, Oyama-Higa. Photoplethysmography technology and its feature visualization for cognitive stimulation assessment. In: Proceedings of the IEEE International Conference on Industrial Technology; 2015. p.7351740. http://dx.doi.org/10.1109/ICIT.2015.7125348

33. Ben-Sadoun G, Sacco G, Manera V, Bourgeois J, König A, Foulan P, et al. Physical and cognitive stimulation using an exergame in subjects with normal aging, mild and moderate cognitive impairment. J Alzheimers Dis. 2016;53(4):1299-314. http://dx.doi.org/10.3233/JAD-160268

34. Djabelkhir-Jemmi L, Wu Y-H, Boubaya M, Marlats F, Lewis M, Vidal J-S, et al. Differential effects of a computerized cognitive stimulation program on older adults with mild cognitive impairment according to the severity of white matter hyperintensities. Clin Interv Aging. 2018;13:1543-54. https:// doi.org/10.2147/CIA.S152225

35. Eckroth-Bucher M, Siberski J. Preserving cognition through an integrated cognitive stimulation and training program. Am J Alzheimers Dis Other Demen. 2009;24(3):234-45. https://doi.org/10.1177/1533317509332624

36. Faucounau V, Wu YH, Boulay M, De Rotrou J, Rigaud AS. Cognitive intervention programmes on patients affected by Mild Cognitive Impairment: a promising intervention tool for MCl? J Nutr Health Aging. 2010;14(1):3135. https://doi.org/10.1007/s12603-010-0006-0

37. Westphal A, Dingjan P, Attoe R. What can low and high technologies do for late-life mental disorders? Curr Opin Psychiatry. 2010;23(6):510-5. https://doi.org/10.1097/YCO.0b013e32833d74d4

38. Viola LF, Nunes PV, Yassuda MS, Aprahamian I, Santos FS, Santos GD, et al. Effects of a multidisciplinar cognitive rehabilitation program for patients with mild Alzheimer's disease. Clinics (São Paulo). 2011;66(8):1395-400. https://doi.org/10.1590/S1807-59322011000800015

39. Dodge $\mathrm{HH}$, Katsumata Y, Zhu J, Mattek N, Bowman M, Gregor M, et al. Characteristics associated with willingness to participate in a randomized controlled behavioral clinical trial using home-based personal computers and a webcam. Trials. 2014;15:508. https://doi.org/ 10.1186/1745-621515-508

40. González-Palau F, Franco M, Bamidis P, Losada R, Parra E, Papageorgiou $S G$, et al. The effects of a computer-based cognitive and physical training program in a healthy and mildly cognitive impaired aging sample. Aging Ment Health. 2014;18(7):838-46. https://doi.org/10.1080/13607863.20 14.899972

41. Toh HM, Ghazali SE, Subramaniam P. The acceptability and usefulness of cognitive stimulation therapy for older adults with dementia: A Narrative Review. Int J Alzheimers Dis. 2016;2016:5131570. https://doi. org/10.1155/2016/5131570

42. Djabelkhir L, Wu YH, Vidal JS, Cristancho-Lacroix, Marlats F, Lenoir H, et al. Computerized cognitive stimulation and engagement programs in older adults with mild cognitive impairment: comparing feasibility, acceptability, and cognitive and psychosocial effects. Clin Interv Aging. 2017;12:196775. https://doi.org/10.2147/CIA.S145769

43. Astell AJ, Smith SK, Potter S, Preston-Jones E. Computer interactive reminiscence and conversation aid groups-delivering cognitive stimulation with technology. Alzheimers Dement (NY). 2018;4:481-7. http://doi. org/10.1016/j.trci.2018.08.003

44. Navarro J, Doctor F, Zamudio V, Iqbal R, Sangaiah AK, Lino C. Fuzzy adaptive cognitive stimulation therapy generation for Alzheimer's sufferers: towards a pervasive dementia care monitoring platform. Future Gener Comput Syst. 2018;88:479-90. https://doi.org/10.1016/j.future.2018.06.018

45. Chen C. Citespace II: Detecting and visualizing emerging trends and transient patterns in scientific literature. J Am Soc Inform Sci Tech. 2006;57(3):359-97. https://doi.org/10.1002/asi.20317

46. Alzheimer Europe. Dementia in Europe Yearbook 2019: Estimating the prevalence of dementia in Europe. Luxembourg: Alzheimer Europe Office; 2019.

47. Villarejo-Galende A, Eimil-Ortiz M, Llamas-Velasco S, Llanero-Luque M, López de Silanes de Miguel C, Prieto-Jurczynska C. Report by the Spanish Foundation of the Brain on the social impact of alzheimer disease and other types of dementia. Neurologia. 2021;36(1):39-49. https://doi. org/10.1016/j.nrl.2017.10.005

48. Gates NJ, Vernooij RWM, Di-Nisio M, Karim S, March E, Martínez G, et al. Computerised cognitive training for preventing dementia in people with mild cognitive impairment. Cochrane Database Syst Rev. 2019;3(3):CD012279. https://doi.org / 10.1002/14651858.CD012279.pub2

49. Irazoki E, Contreras-Somoza LM, Toribio-Guzmán JM, Jenaro-Río C, van der Roest H, Franco-Martín MA. Technologies for cognitive training and cognitive rehabilitation for people with mild cognitive impairment and 
dementia. A Systematic Review. Front Psychol. 2020;11:648. https://doi. org/10.3389/fpsyg.2020.00648

50. United Nations. Department of Economic and Social Affairs. World Population Prospects 2019 - Population Division. 2019 [accessed on Jun 20, 2020]. Available at: https://population.un.org/wpp/

51. OCDE. Elderly population (indicator). 2020 [accessed on Jun 20, 2020]. Available at: https://data.oecd.org/pop/elderly-population.htm

52. Qiu C, Fratiglioni L. Aging without Dementia is Achievable: Current Evidence from Epidemiological Research. J Alzheimers Dis. 2018;62(3):933-42. https://doi.org/10.3233/JAD-171037

53. Prince M, Bryce R, Albanese E, Wimo A, Ribeiro W, Ferri CP. The globa prevalence of dementia: a systematic review and metaanalysis. Alzheimers Dement. 2013;9(1):63-75.e2. https://doi.org/10.1016/j.jalz.2012.11.007
54. Prince MJ, Wimo A, Guerchet MM, Ali GC, Wu Y-T, Prina M, World Alzheimer Report 2015 - The Global Impact of Dementia: an analysis of prevalence, incidence, cost and trends. Alzheimer's Disease International; 2015 [accessed on Jul 20, 2020]. Available at: https://www.alzint.org/u/ WorldAlzheimerReport2015.pdf

55. World Health Organisation, Global action plan on the public health response to dementia 2017-2025. WHO; 2017 [accessed on Jul 21, 2020]. Available at: https://www.who.int/mental_health/neurology/dementia/ action_plan_2017_2025/en/

56. Alzheimer's Association. 2020 Alzheimer's disease facts and figures. Alzheimers Dement. 2020. [Online ahead of print]. https://doi.org/10.1002/alz.12068

57. Venneri A. Imaging treatment effects in Alzheimer's disease. Magn Reson Imaging. 2007;25(6):953-68. https:do.org/10.1016/j.mri.2007.02.004 